\author{
Asian Journal of \\ Medical and Biological Research \\ ISSN 2411-4472 (Print) 2412-5571 (Online) \\ www.ebupress.com/journal/ajmbr
}

\title{
Article \\ Comparative study on microbial and botanical pesticides as biorational control of mango hopper
}

\author{
Md. Sohanur Rahman ${ }^{1 *}$, Md. Arifur Rahman ${ }^{2}$, Md. Mukul Mia ${ }^{3}$ and Mahbuba Jahan ${ }^{4}$ \\ ${ }^{1}$ Pest Management Division, Bangladesh Jute Research Institute, ManikMia Avenue, Dhaka-1207, Bangladesh \\ ${ }^{2}$ Department of Agricultural Chemistry, Bangladesh Agricultural University, Mymensingh-2202, Bangladesh \\ ${ }^{3}$ Breeding Division, Bangladesh Jute Research Institute, ManikMia Avenue, Dhaka-1207, Bangladesh \\ ${ }^{4}$ Department of Entomology, Bangladesh Agricultural University, Mymensingh-2202, Bangladesh
}

*Corresponding author: Md. Sohanur Rahman, Pest Management Division, Bangladesh Jute Research Institute, ManikMia Avenue, Dhaka-1207, Bangladesh. Phone: +8801734 209889; E-mail: sohanbau2010@gmail.com

Received: 16 November 2019/Accepted: 28 December 2019/ Published: 31 December 2019

\begin{abstract}
Mango hopper is considered as one of the most destructive pests of mango in Bangladesh which can be effectively controlled by using bio-agents and botanical pesticides. An experiment was conducted at the IPM Laboratory of the Department of Entomology, Bangladesh Agricultural University, Mymensingh, Bangladesh to study the comparative performance of three botanicals (Neem, Mahogany and Karanja oils) and a microbial pesticides (Beauveria bassiana) for the management of mango hopper (Idioscopus clypealis). The experiment was designed following completely randomized design (CRD) using 39 petridishes of $12 \mathrm{~cm}$ in diameter. Four insecticides each with 3 different doses $(1 \%, 2 \%$ and $3 \%$ ) were evaluated for their effectiveness. The data on the number of hopper killed were collected every day of a week. Results showed that all the three doses of Beauveria bassiana effectively controlled mango hopper. All the treatments influenced significantly in the management of mango hopper in comparison to the control. Among the botanicals 3\% Neem oil was the most effective best but relatively lower performance was observed in case of 1\% Mahogany oil. Observation on the effect of a microbial pesticide (Beauveria bassiana) and some botanicals on the infestation of mango hopper at different stages showed that hopper population at pea-shaped after prior to the second spray was maximum in $1 \%$ Mahogany oil (13.87) and minimum number of hopper was found in 3\% Beauveria bassiana (7.33). Overall results suggested that Beauveria bassiana as a microbial pesticide performed better than botanicals in controlling mango hopper and resulting in higher yield.
\end{abstract}

Keywords: mango hopper; microbial; botanicals; management

\section{Introduction}

Bangladesh is well known for the production of mango fruit along with other countries of the world including India, Pakistan, the Philippines, Brazil and Mexico. In Bangladesh, mango occupies about an area of 50,491 ha with a production of 187220 tones (BBS, 2003). It is now in an increasing trend in the area by $112 \%$ and in production by $116 \%$ in the year of 2000-2001 compared to 1984-1985 (BBS, 2002). As a leading seasonal cash crop of the northwestern region of Bangladesh, mango dominates the economy in two important cities namely Chapainawabganj and Rajshahi districts. It is considered as the "king of fruits". Insect pest and diseases are the main factors that affect mango production and yield. There are about 30 species of insect pests which have been reported as pests of mango in Bangladesh. Mango hopper (Idioscopus clypealis Leth.) is the most serious pest of mango fruit cultivation (Saeed et al., 2013). Of all the mango pests, hopper (Idioscopus clypealis) is considered as the most serious and widespread pest throughout the country. The vigour of the plants can be reduced when the adult insects puncture and suck the sap of the tender parts of the shoots. They also damage the crop by secreting a sweet sticky substance which facilitates the development of the fungus Maliola managiferae, 
commonly known as sooty mould affecting adversely the photosynthetic activities of the leaves. Generally, in February-April and June-August the population of mango hopper shoots up.

Mango (Mangifera indica) is an evergreen tree in the family Anacardiaceae grown for its edible fruit. It is believed to originate from India or Burma (Myanmar). The mango hopper is the serious pest of mango at flowering and fruiting stages and yield loss could be 80-100 percent (Rahman, 2007). Both nymphs and adults aggregate on the underside of leaves and suck the sap of tender shoots, young leaves and inflorescence. The infested florets turn brown and dry up which adversely affects fruit setting. Hopper infestation also causes honeydew secretion resulting in sooty mould formation affecting photosynthesis and also stains the fruits which reduce the market value (Rahman, 2007). Presently only insecticidal control is available for management of mango hoppers. Considering the deleterious effects caused by chemicals to the beneficial organisms in mango ecosystem and the demand for organic production of mango there is a need to develop alternate, safe and ecofriendly management strategy for the control of mango hoppers. Among all mango pests, mango hoppers is considered to be the most serious and widespread pest, with a potential to cause up to $100 \%$ loss in India, the world's largest producer of mango. Nymph and adult insects puncture and suck the sap of the tender shoots which reduce vigour (Visalakshi et al., 2010; Rahman, 2007; Varshneya and Rana, 2008). Both nymph and adult cause damage of leaf and inflorescence and sometimes younger leaves by sucking plant sap. The infested leaf dries up and panicle shrivels, turns brown and ultimately dies. During heavy infestation, honeydew excreted by the mango hoppers encourages the development of the black shooty mould (fungus) on the surface of the leaves, inflorescence, branches and shoots that interferes with the photosynthetic activity of the affected plant parts, ultimately resulting in non-setting of flowers dropping of the immature fruits. The mango hoppers may thus cause a loss of $20-100 \%$ of the inflorescence (Hossain, 1989). Severely infested plants bear only a few fruits or no fruits at all. Because of the great economic importance of the mango hoppers, many studies have been conducted on their extent of damage and their control. But so far, no in-depth studies on these regards have been made in Bangladesh. A fungus, Beauveria bassiana has also been found effective against this pest but under moderate climate. Spraying of Nimbicidine (0.2\%) is effective at the initial stage of hoppers management. The present control method is based purely on chemicals, especially synthetic insecticides. But indiscriminate use of persistent insecticides is causing several problems such as disrupting natural enemy complexes, development of insecticide resistance, secondary pest outbreak, pest resurgence, and environmental pollution. To overcome these problems farmers can shift from the unilateral reliance on insecticide use to bioratioal approaches. A significant role might be played by natural plant products as they are environmentally biodegradable, safe and cost-effective. Several chemical compounds from seeds and leaves of many plant species have already isolated and identified, and screened out many as growth inhibitors and insect feeding deterrents. In this situation, biodegradable substitutes are now being strongly conceived by all scientists of the world. Among the botanicals, products of Neem (Azadirachta indica) have extensively been used to control many pests and have already proved their efficacy against several types of insect pests both in field and storage. However, exploration on the use of botanicals especially Mahogany and Karanja against mango pests is scanty in Bangladesh. The present study was performed to know the potentially of three nonpersistence natural product, namely, Neem oil, Mahogany and Karanja and as well as a fungus, Beauveria bassiana to manage mango hopper, I. clypealis (Lethierry), along with the assessment of their toxic effects on mango hopper and flower and fruit retention. However, sufficient information on mango hopper and the effectiveness of biorational pesticide in controlling mango hopper in Bangladesh is sporadic and published information in the scientific journal is not available. This research work on mango hopper would provide significant information to protect the mango flower and fruit from the attack of the pest and thereby will increase the yields which ultimately increase the farmer's economy as well as the economy of the country.

\section{Materials and Methods}

\subsection{Experimental site}

The study was conducted at the Entomology IPM Laboratory, Department of Entomology, Faculty of Agriculture, Bangladesh Agricultural University, Mymensingh, Bangladesh from February 2014 to March 2015. To conduct the experiments six mango trees of Amrapali variety were selected in Aqua, Mymensingh and trial was conducted in Entomology Field Laboratory, BAU, Mymensingh. The experimental area was characterized by moderately low temperature, low humidity and scanty rainfall during the February 2014 to April 2015.

\subsection{Collection of microbial and botanical pesticides}

Botanical insecticides i.e., Neem (Azadirachta indica), Mahogany (Swietenia mahagoni) and Karanja (Millettia pinnata) oils were collected from IPM Laboratory of Entomology Department, Bangladesh Agricultural 
University (BAU), Mymensingh. A microbial pesticide (Beauveria bassiana) was collected from Ispahani Biotech Company in Bolaspur, Mymensingh. A commercial formulation of Beauveria bassiana was used to conduct the experiment.

\subsection{Treatments and experimental design}

Botanical insecticides were used with a dose of $1 \%, 2 \%$ and $3 \%$ of each. The doses of used Beauveria bassiana were $1 \%, 2 \%$ and $3 \%$. For all insecticides, at first 39 petridishes $(12 \mathrm{~cm}$ diameter) were taken. Fresh, diseasefree and well-developed inflorescences, (approximately $10 \mathrm{~cm}$ in length) were collected. Completely randomized design (CRD) was used in this study.

\subsection{Experimental setup}

Four insecticides each with 3 different doses were evaluated for their efficiency. One inflorescence was placed in each petridish. Insecticide was sprayed on each inflorescence placed in petridishes and left for air dry before offering insect. Among the 39 petridishes, $(3 \times 3 \times 3)=27$ petridishes were used for treatment. Then 10 hoppers $(7$ adults +3 nymphs) were released at each petridish and kept for 7 days. Similarly, In case of Beauveria bassiana, 9 petridishes $(12 \mathrm{~cm}$ diameter) were taken. Fresh, disease-free and well-developed inflorescences, (approximately $10 \mathrm{~cm}$ in length) were collected. One inflorescence was placed in each petridish. Insecticide was sprayed on each inflorescence placed in petridishes and left for air dry before offering insect. $(3 \times 3)=9$ petridishes were used for treatment and 3 petridishes were used for control for all insecticides. Small pieces of cotton with soaked fertilized water were placed at the base of the inflorescence to keep the inflorescence fresh.

\subsection{Protection measures}

Cotton pieces were changed regularly to avoid the probability of development of fungus and some fertilized water was added to the cotton pieces regularly. In the laboratory, daily temperature and humidity were recorded and maintained. The data on the number of hoppers killed were collected at 1 DAT, 2 DAT, 3 DAT, 4 DAT, 5 DAT, 6 DAT and 7 DAT.

\subsection{Statistical analysis}

Obtained data were analyzed statistically after appropriate transformation using analytical computer software MSTAT-C and mean values were separated using DMRT.

\section{Results and Discussion}

\subsection{Comparative toxicity test of microbial pesticide and botanicals in the laboratory}

The data regarding comparative toxicity of insecticides on the basis of the number of hoppers killed are presented in Table 1. The experimental result revealed significant superiority of microbial pesticide to botanicals. In the present study after 5 days of microbial pesticide treatment, it was found that two doses of Beauveria bassiana (2\% and 3\%) were enough to kill hundred percent of insect offered. After 6 days of insecticidal treatment, it was found that all doses of Beauveria bassiana and one dose of Neem oil (3\%) were enough to kill hundred percent of insect offered. But the lower number of insects was killed in Karanja oil (1\%) treatment. No mortality was found where insecticide was not applied. Among the botanicals it was found that Neem oil had better performance and Karanja oil was found least effective. After 2 days and 3 days of treatment, the highest result was found in $3 \%$ Neem oil (7.67) which was statistically similar to $2 \%$ and $3 \%$ Neem oil. But the lower result was found in case of $1 \%$ Karanja oil.

Similarly, after 5 days and 6 days of treatment, the highest result was found in 3\% Neem oil (8.87). But the lowest result was found in case of $1 \%$ Karanja oil (6.75). Three (3\%) Neem oil took 5 days to kill about 8.87 insects whereas 3\% Karanja oil took 7 days to cause the statistical similar effect (8.67). Beauveria bassiana (2\% and 3\%) and Neem oil 3\% killed all the insects after 7 days but only 6.33 insects were killed in control treatment. Srivastava and Tandon (1986) reported that entomopathogenic fungi, such as Beauveria bassiana was effective against mango hopper. The study between microbial pesticide (Beauveria bassiana) and botanicals against mango hopper shows that the performance of microbial pesticide (Beauveria bassiana) was better than that of botanicals which were similar to the findings of Singh (2008). BARI (2013) also reported that microbial pesticide (Beauveria bassiana) was an effective bio-rational based management option for the control of mango hopper. Among botanicals, the highest performance was found in 3\% Neem oil (10.0) whereas the lowest result was found in 1\% Karanja oil (4.15). Similar finding on the efficacy of Neem oil was also reported by Adnan $e t$ al. (2014) wherein Neem oil was found effective against mango hopper. 
3.2. Effect of a microbial pesticide and botanicals on the infestation

Results revealed that after one month of the first spray, the number of the hopper at the flowering stage was the maximum in 3\% Mahogany oil (15.17) and lowest hopper was found in 2\% Karanja oil (Figure 1). It indicated that $2 \%$ Karanja oil had the better effect than any other insecticide at flowering stage. But hopper population at pea-shaped after prior to second spray was maximum in 1\% Mahogany oil (13.87) and the minimum number of hopper was found in 3\% Beauveria bassiana (7.33) (Figure 2). But at control condition, the number of hopper was 16.20 which were higher than that of treated one. So it can be said that insecticides have effect against mango hopper. Fifteen (15) days after second spray (15 DAP) no hopper was found in all the three doses of Beauveria bassiana and maximum number of hopper were found also in mahogoni oil 1\% (12.37) (Figure 3). But among the botanicals the minimum numbers of hopper were found in $2 \%$ and $3 \%$ Neem oil and $3 \%$ Karanja oil. In controlled plant, hopper population was 15.59 while in treated with all doses of Beauveria bassiana hopper population was zero at the same time. So, Beauveria bassiana had better performance on fruit setting of mango among all insecticidal treatments. Among botanicals 2\% and 3\% Neem oil had better performance on fruit setting of mango inflorescence. It was surely noted that fruit-bearing was better in inflorescence treated with microbial pesticide (Beauveria bassiana) than botanicals. From the table it is said that higher the infestation of hopper, lower the fruit setting of inflorescence. Prabhakara et al. (2011) found in their research work on Beauveria bassiana against mango hopper that maximum hopper population reduction was recorded in the highest doses of Beauveria bassiana. This study also represents the same result that higher doses of Beauveria bassiana are responsible for higher \% of hopper population mortality.

Similar trend was observed when cumulative hopper population caught in sticky trap was recorded and the lowest was found in the control and the lowest in Neem treated plants followed by different doses of a fungus with a clear indication that the dosage had a positive impact in the reduction of hopper population.

Table 1. Comparative toxicity of a microbial pesticide (Beauveria bassiana) and some botanicals in the laboratory.

\begin{tabular}{|c|c|c|c|c|c|c|c|}
\hline \multirow{2}{*}{ Treatments } & \multicolumn{7}{|c|}{ Average no. of hopper (Adult+Nymph) killed at different interval } \\
\hline & 1 DAT & 2 DAT & 3 DAT & 4 DAT & 5 DAT & 6 DAT & 7 DAT \\
\hline Beauveria bassiana $1 \%$ & $3.41 \mathrm{ab}$ & $4.67 \mathrm{ef}$ & $7.12 \mathrm{~cd}$ & $7.97 \mathrm{bc}$ & 8.33abcde & $9.63 \mathrm{ab}$ & - \\
\hline Beauveria bassiana $2 \%$ & $3.57 \mathrm{ab}$ & $6.75 \mathrm{bc}$ & $7.55 \mathrm{bcd}$ & $8.33 \mathrm{ab}$ & $8.67 \mathrm{abc}$ & $10.00 \mathrm{a}$ & - \\
\hline Beauveria bassiana $3 \%$ & $3.90 \mathrm{a}$ & $7.10 \mathrm{~b}$ & $8.87 \mathrm{a}$ & $9.17 \mathrm{a}$ & 9.67 a & $10.00 \mathrm{a}$ & - \\
\hline Neem oil $1 \%$ & $3.00 \mathrm{bc}$ & $5.93 \mathrm{~d}$ & $6.83 \mathrm{~d}$ & $7.15 \mathrm{~cd}$ & $8.13 \mathrm{abcde}$ & $8.67 \mathrm{bc}$ & $9.11 \mathrm{bc}$ \\
\hline Neem oil $2 \%$ & $3.33 \mathrm{ab}$ & $6.40 \mathrm{~cd}$ & $7.93 \mathrm{abc}$ & $8.15 \mathrm{bc}$ & $8.53 \mathrm{abcd}$ & $9.00 \mathrm{abc}$ & $9.33 \mathrm{abc}$ \\
\hline Neem oil $3 \%$ & $3.67 \mathrm{a}$ & $7.67 \mathrm{a}$ & $8.33 \mathrm{ab}$ & $8.67 \mathrm{ab}$ & $8.87 \mathrm{ab}$ & $9.33 \mathrm{ab}$ & $10.00 \mathrm{a}$ \\
\hline Mahogany oil $1 \%$ & $2.33 \mathrm{~d}$ & $4.20 \mathrm{f}$ & $5.73 \mathrm{ef}$ & $6.20 \mathrm{de}$ & 7.33 bcde & $8.14 \mathrm{~cd}$ & $8.67 \mathrm{~cd}$ \\
\hline Mahogany oil $2 \%$ & $2.67 \mathrm{~cd}$ & $5.08 \mathrm{e}$ & $6.65 \mathrm{de}$ & $7.19 \mathrm{~cd}$ & 7.67 bcde & $8.63 \mathrm{bc}$ & $9.33 \mathrm{abc}$ \\
\hline Mahogany oil 3\% & $3.00 \mathrm{bc}$ & $6.11 \mathrm{~d}$ & $7.22 \mathrm{~cd}$ & $7.67 \mathrm{bc}$ & $8.21 \mathrm{abcde}$ & $8.91 \mathrm{bc}$ & $9.67 \mathrm{ab}$ \\
\hline Karanja oil $1 \%$ & $2.10 \mathrm{~d}$ & $4.15 \mathrm{f}$ & $5.15 \mathrm{f}$ & $6.00 \mathrm{e}$ & $6.75 \mathrm{e}$ & $7.33 \mathrm{~d}$ & $8.17 \mathrm{~d}$ \\
\hline Karanja oil $2 \%$ & $2.23 \mathrm{~d}$ & $4.19 \mathrm{f}$ & $5.33 \mathrm{f}$ & $6.25 \mathrm{de}$ & $7.00 \mathrm{de}$ & $7.39 \mathrm{~d}$ & $8.33 \mathrm{~d}$ \\
\hline Karanja oil 3\% & $2.50 \mathrm{~cd}$ & $4.97 \mathrm{e}$ & $5.67 \mathrm{ef}$ & $6.33 \mathrm{de}$ & 7.20 cde & $8.00 \mathrm{~cd}$ & $8.67 \mathrm{~cd}$ \\
\hline Control & $0.00 \mathrm{e}$ & $1.87 \mathrm{~g}$ & $2.67 \mathrm{~g}$ & $3.91 \mathrm{f}$ & $4.67 \mathrm{f}$ & $6.10 \mathrm{e}$ & $6.33 \mathrm{e}$ \\
\hline $\mathrm{LSD}_{0.05}$ & 0.564 & 0.543 & 0.987 & 0.931 & 1.39 & 0.930 & 0.669 \\
\hline $\mathrm{CV}(\%)$ & 12.22 & 6.09 & 8.99 & 7.76 & 10.71 & 6.49 & 5.92 \\
\hline
\end{tabular}

Means followed by different letters (using DMRT) in a column are significantly different and DAT $=$ Days After treatment. Means followed by different letters (using DMRT) in a column are significantly different. DAP = Days After Pea Shaped, PFS $=$ Prior to First Spray, PSS $=$ Prior to Second Spray and DASS $=$ Days after Second Spray. 


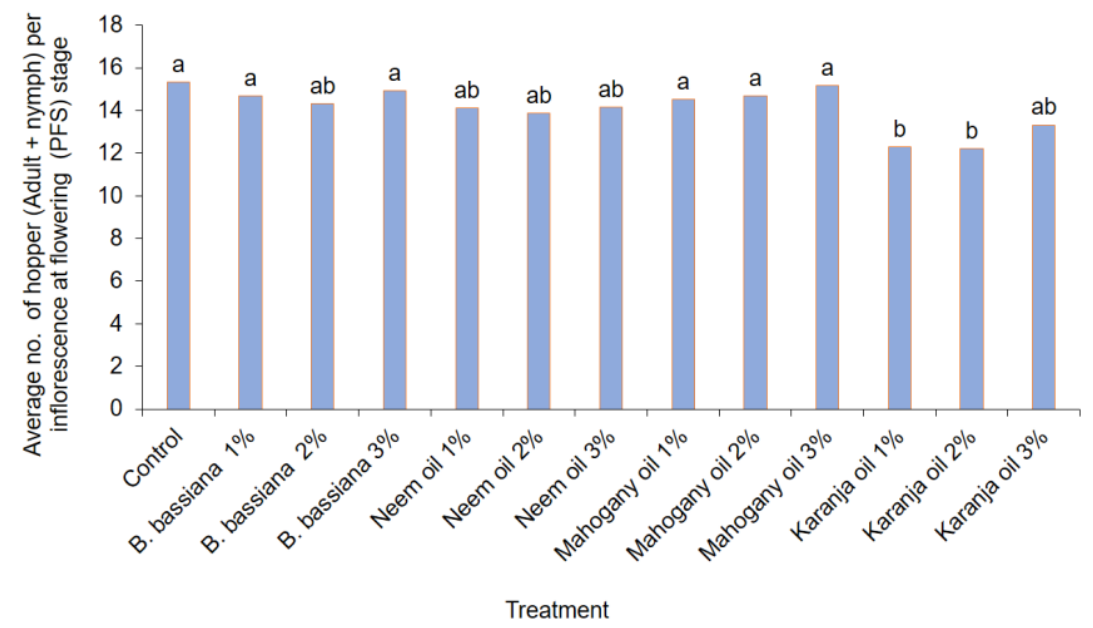

Figure 1. Effect of a microbial (Beauveria bassiana) and botanical pesticides on the infestation of mango hopper at flowering (PFS) stages.

PFS $=$ Prior to First Spray

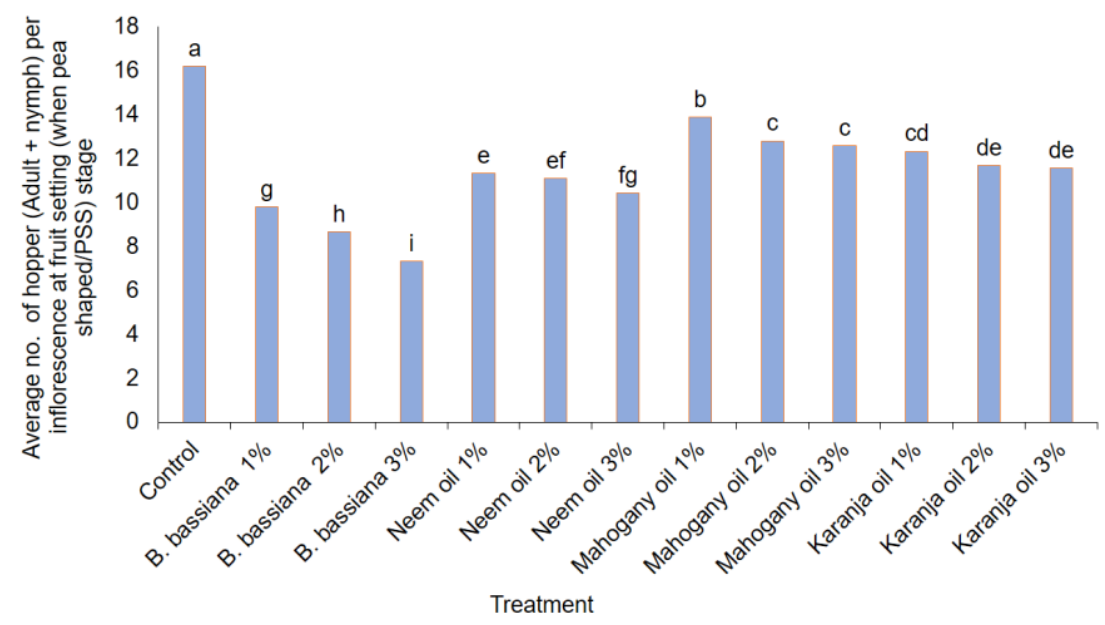

Figure 2. Effect of a microbial (Beauveria bassiana) and botanical pesticides on the infestation of mango hopper at fruit setting (when pea shaped/PSS) stage. PSS = Prior to Second Spray.

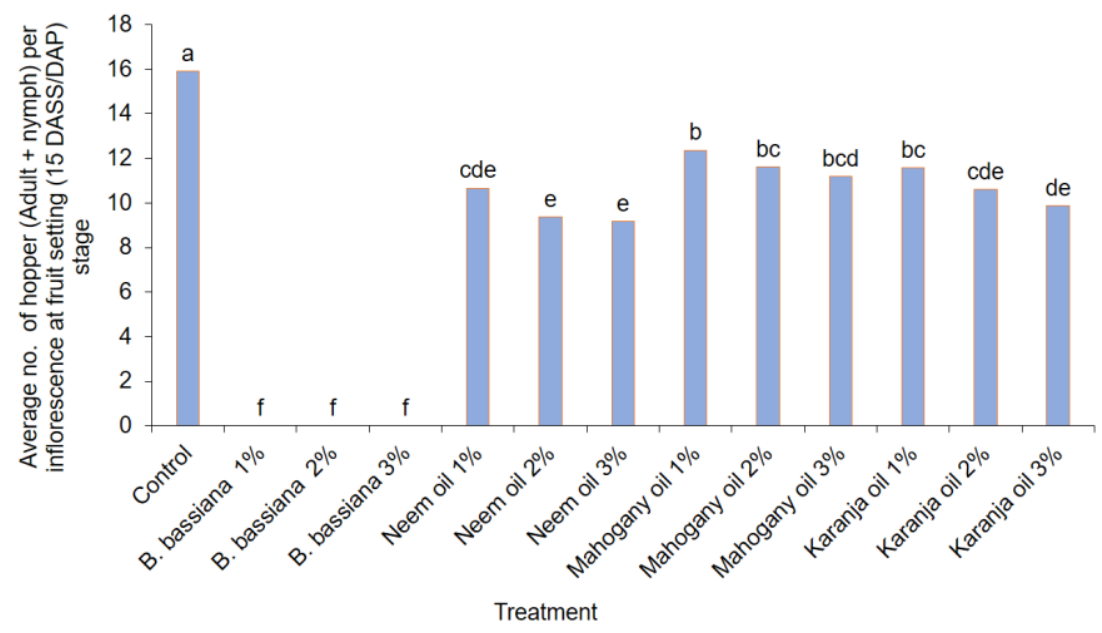

Figure 3. Effect of a microbial (Beauveria bassiana) and botanical pesticides on the infestation of mango hopper at fruit setting (15 DASS/DAP) stage. DAP = Days After Pea Shaped and DASS = Days after Second Spray. 


\section{Conclusions}

It can be concluded that $1 \%$ Beauveria bassiana was highly toxic to mango hopper. Among the botanicals Neem oil was the highly toxic but Mahogany oil was less toxic. The highest number of hopper was killed by $3 \%$ Neem oil and the lowest by 1\% Mahogany oil. This experiment revealed that after one month of first spray, the number of hopper at flowering stage was the maximum in 3\% Mahogany oil (15.17) and lowest hopper was found in $2 \%$ Karanja oil. But hopper population at pea shaped after prior to second spray was maximum in $1 \%$ Mahogany oil (13.87) and minimum no. of hopper was found in 3\% Beauveria bassiana (7.33). On the basis of hopper infestation after insecticidal treatment it was noted that Beauveria bassiana had the better effect in controlling mango hopper than any other insecticide. Among the botanicals the minimum numbers of hopper were found in 2\%, 3\% Neem oil and 3\% Karanja oil.

\section{Conflict of interest}

None to declare.

\section{References}

Adnan SM, MM Uddin, MJ Alam, MS Islam, MA Kashem, MY Rafii and MA Latif, 2014. Management of mango hopper, Idioscopus clypealis, using chemical insecticides and neem oil. Sci.World J., 2014: 1-5.

BARI, 2013. Development of bio-rational based management approach against mango hopper, Lac Research Station, Chapai Nawabgonj. Annual Report, Entomology Division, BARI, Gazipur.

BBS, 2002. Statistical Yearbook of Bangladesh. Bangladesh Bureau of Statistics. Ministry of Planning, Government of the People's Republic of Bangladesh. Dhaka, Bangladesh. p. 152.

BBS, 2003. Statistical Yearbook of Bangladesh. Bangladesh Bureau of Statistics. Ministry of Planning, Government of the People's Republic of Bangladesh. Dhaka, Bangladesh.

Hossain AKMA, 1989. A field guide on insect pests and diseases of mango in Bangladesh and their control. Bangladesh Agril. Res. Inst., Gazipur. p. 44.

Hossain AKMA, 1989. Manual on Mango Cultivation in Bangladesh.Horticulture Division, BARI, Gazipur. p. 82.

Prabhakara MS, SK Ghosh and C Malvika, 2011. Field efficacy of Myco-jaal, an oil based commercial formulation of Beauveria bassiana (Deuteromycotina: Hyphomycetaceae) against mango inflorescence hopper, Idioscopus nitidulus (Walker). Pest Manag. Hort. Eco., 17: 140-143

Rahman SMA, 2007. Mango hopper: Bioecology and management- A review. Agric. Rev., 28: 49-55.

Saeed S, MA Amin, Q Saeed and M Farooq, 2013. Attraction of Idioscopus clypealis (Leith) (Cicadellidae: Homoptera) to sticky colored traps in mango orchard. Am. J. Plant Sci., 4: 2275-2279.

Singh R, 2008. Evaluation of some biopesticides against mango hoppers (Idioscopus clypealis and Amritodus atkinsoni) and flower visitors of mango. Indian J. Plant Prot., 36: 24-27.

Srivastava RP and PL Tandon, 1986. Natural occurrence of two entomopathogenic fungi pathogenic to mango hopper Idioscopu clypealis Leth. Indian J. Plant Pathol., 4: 121-123.

Varshneya A and KS Rana, 2008. Effect of some abiotic factors on population buildup of Idioscopus clypealis Leth. In western Uttar Pradesh. J Environ. Biol., 29: 811-812.

Visalakshi P, J Arora and D Behera, 2010. Evaluation of nitrate reductase assay for rapid detection of resistance to second-line drugs in Mycobacterium tuberculosis in a tertiary care hospital. Diagn. Microbiol. Infect. Dis., 68: $236-240$. 